Brit. J. vener. Dis. (1961), 37, 161.

\title{
TREATMENT OF GONORRHOEA WITH PHENETHICILLIN (BROXIL)*†
}

\author{
BY \\ F. J. G. JEFFERISS AND N. ROSEDALE \\ St. Mary's Hospital, London
}

Broxil (BRL 152), the potassium salt of 6( $\alpha$ phenoxyproprionamide)-penicillanic acid (Phenethicillin) when given orally, is claimed to give penicillin blood levels two or three times as high as those obtained by penicillin $\mathrm{V}$, and at least equal to those obtained by intramuscular injections of penicillin G. A trial of this drug in the treatment of gonorrhoea in male patients was started in November, 1959.

\section{Material}

The patients treated with Broxil were taken from those attending the clinic at St. Mary's Hospital London, with acute gonococcal urethritis, both first attacks and re-infections. We excluded those about to leave the district and therefore unable to attend for routine follow-up, a small number with complications of gonorrhoea (e.g. epididymitis), those with genital ulceration, and those who gave a definite history of penicillin sensitivity.

\section{Dosage}

At first, a single dose of $1,000 \mathrm{mg}$. (four 250-mg. tablets) was used. However, after the treatment of only five cases with this dosage, it became obvious that a divided dosage would be advisable. Two of the first five patients developed symptoms of acute indigestion soon after taking the tablets, followed, on the next day, by "black diarrhoea" presumably due to acute gastric irritation. Three of them were cured of their gonorrhoea but the other two failed to respond.

This dosage schedule was therefore abandoned and the next hundred patients were given two doses, each of $500 \mathrm{mg}$. The first dose (two 250-mg. tablets) was

* Received for publication August 2, 1960.

+ Paper read at the European Symposium of the I.U.V.D.T. at Cracow, Poland, in September, 1960. given at the clinic and two more tablets were to be taken by the patient after a specified interval. With this arrangement, there were no complaints of any illeffects. We had been advised that the drug should be given, as far as possible, on an empty stomach and this was attempted in earlier cases but was given up owing to practical difficulties. There was no apparent deterioration in effect as a result of this change.

The first sixty patients were given $500 \mathrm{mg}$. (two tablets) on the first visit to the clinic and were instructed to take a further two tablets after 8 hours. The remaining forty patients were told to take the second dose after 4 hours.

\section{Results}

Of the 100 patients treated with the divided dosage, twelve failed to respond and were re-treated by other means. The proportion of failures in racial groups was as follows:

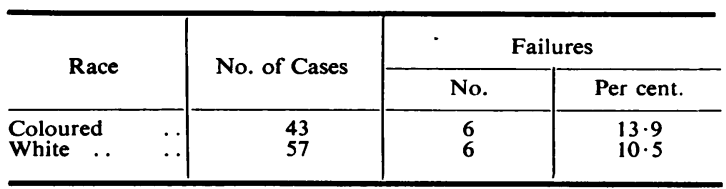

Of the apparently successful cases, about one-third remained under observation for from 1 to 3 weeks, one-third for less than 1 week, and one-third failed to return for any follow-up at all.

Although this is obviously very unsatisfactory in assessing the results of treatment, we have found, over the years, that many of our patients, particularly West Indians, will return to the clinic only if any urethral symptoms persist. Their very prompt return at the first sign of discharge or even occasional dysuria strongly suggests that default indicates an absence of signs or symptoms and a probable cure. 
Comparison with Penicillin by Injection.-For some time, our routine treatment of uncomplicated urethral gonorrhoea in the male had been a single injection of 600,000 units aqueous procaine penicillin. A random sample of 200 consecutive cases of gonorrhoea treated in this way showed an overall failure rate of 6.5 per cent. $(9 \cdot 3$ per cent. in coloured patients and 3.9 per cent. in white patients).

\section{Discussion}

This pilot study of 100 cases of gonorrhoea treated orally with Broxil (in two doses of $500 \mathrm{mg}$. each) has shown a failure rate of 12 per cent. in comparison with a failure rate of 6.5 per cent. in a similar group treated with a single injection of 600,000 units aqueous procaine penicillin.

It may be that some modification of this dosage schedule (e.g. one tablet of $250 \mathrm{mg}$. 4-hrly for 4 doses) or an increase in the total dose might produce results more closely comparable with treatment by injection. Other considerations involved include the following:

(1) Cost. $-1,000 \mathrm{mg}$. Broxil costs $3 / 8 \mathrm{~d}$. as compared with $11 \mathrm{~d}$. for 600,000 units aqueous procaine penicillin. These prices are related to buying in bulk by a hospital dispensary. The cost of preparing a sterile syringe and the time taken for the injection by the clinic nursing staff must be balanced against the higher cost of tablet treatment.

(2) Accurate Dosage.-The absorption of a drug taken orally is less predictable than that of an injected preparation. Another important factor is the intelligence of the patient to whom a drug is given. Our experience of giving courses of sulphonamide tablets to V.D. clinic patients suggests that only a minority is capable of taking tablets exactly as instructed. Some of our patients would be very likely to keep some tablets back for "next time", or to pass them on to others.

(3) Antibacterial Efficiency.-Garrod (1960) has shown that penicillin $G$ is eight times more effective against the gonococcus in vitro than penicillin $\mathrm{V}$ or Broxil.

For these reasons, although it would obviously be of interest to determine the most efficient dosage schedule of Broxil for the cure of gonorrhoea, we feel that treatment should continue to be given in the form of injections and not by tablets taken orally.
Comparing our findings with other recently reported series of cases treated with oral penicillin, Willcox (1958) treated a series of 85 males with one to two oral doses of 2 to 3 mega units penicillin $\mathrm{V}$. In 33 white patients there was a 14.8 per cent. recurrence rate (all suspected of being re-infections). In 52 coloured patients there was a 40.8 per cent. recurrence rate, seven out of ten of which were considered to be failures. In an earlier series, Shiel (1956) treated 28 males with oral penicillin V; 25 had 3.6 mega units in divided doses over 3 days; two had 1.2 mega units in 1 day; and one had 2.4 mega units over 2 days. There was only one failure, and that was believed to have been a re-infection.

A matter for consideration is the difficulty of accurate identification of a treatment failure as opposed to a re-infection. In almost every case, in the treatment of out-patients, this differentiation depends entirely on a truthful history from the patient.

New cases of gonorrhoea attending this clinic are at present almost equally divided between white and coloured patients, but 65 per cent. of the admitted re-infections occur in coloured patients.

The difference in treatment failure rates between white and coloured patients recorded above $(9 \cdot 3$ per cent. coloured, 3.9 per cent. white) suggests that one factor may be the inaccurate histories given by some of the coloured patients.

It is worth noting that some of the "treatment failures" among our coloured patients occurred in the most promiscuous or least intelligent (often both!), organisms cultured from these "treatment failures" seldom showing any degree of insensitivity to penicillin.

\section{Summary}

A small series of cases of uncomplicated gonococcal urethritis in male patients treated with 1,000 mg. oral Broxil (Phenethicillin) in two doses of $500 \mathrm{mg}$. has shown a treatment failure rate of 12 per cent. as compared with 6.5 per cent. in a similar group treated with a single injection of 600,000 units procaine penicillin. The identification of "treatment failure" and re-infection in any series depends on obtaining an accurate history from the patient. It is suggested that the higher recorded incidence of treatment failure in coloured patients can be explained by the inaccurate histories given 
by a group of highly promiscuous individuals. Any treatment schedule involving the taking of tablets at specified times after leaving the clinic may be subject to modification by unreliable patients. We consider that in the treatment of gonorrhoea penicillin should be given by injection and not orally.

Our thanks are due to Beecham Research Laboratory Ltd. for the supply of Broxil tablets.

\section{REFERENCES}

Garrod, L.P. (1960). Méd. et Hyg. (Genève), 18, 665

Shiel, L. P. (1956), Brit. J. vener. Dis., 32, 251.

Willcox, R. R. (1958). Ibid., 118.
Traitement de la gonorrhée par le Broxil (Phénéthicilline)

Résumé

Quand deux doses de $500 \mathrm{mg}$. de Broxil (Phénéthicilline) furent administrées par voie buccale à un petit nombre d'hommes atteints d'urétrite gonococcique simple, le traitement échoua dans $12 \%$ des cas. Dans une même série traitée par une seule injection de 600.000 unités de pénicilline-procaine, il y eut $6,5 \%$ d'échecs. On ne peut, dans aucune série, parler d'échec et de réinfection qu'après avoir dissipé tous les doutes sur les antécédents du malade. D'après les auteurs, le plus grand nombre d'échecs enregistrés chez les malades de couleur s'explique parl'inexactitude des antécédents fournis par un groupe d'individus adonnés à la promiscuité. Quand le malade doit prendre des comprimés régulièrement après avoir quitté la clinique, le traitement peut être modifié par un malade irresponsable.

Les auteurs considèrent que, dans le traitement de la gonorrhée, la pénicilline doit être administrée par injection, et non pas par voie buccale. 